\title{
PENGEMBANGAN EKONOMI PADA LIMA PESANTREN KABUPATEN LAMONGAN, JAWA TIMUR
}

\author{
Achmad Dudin \\ Peneliti Puslitbang Pendidikan Agama dan Keagamaan \\ Badan Litbang dan Diklat Kementerian Agama Republik Indonesia \\ Jl. MH Thamrin No. 06 Jakarta Pusat \\ ahmaduddin@yahoo.com
}

\begin{abstract}
This writing isthe result of research on economic development in 5 Islamic boarding schools (pesantren) in Lamongan, East Java, 2010. This research is rooted in the context of economic development among the people, as Islamic boarding schools are challenged with improving standards of living in the form of business activities, including the potential human resources in local communities. The objective of the research was to support the Islamic boarding school in economic development through supervision. This research applied several methods including: selecting 5 Islamic boarding schools by the team to be executors of the program and financial support for orientation activities focused on the funding and business development of animal husbandry, as well as the execution of supervising, monitoring, evaluating, and reflecting on the program in order to reach the target of Islamic boarding school economic development. The result is the increase in the economic management and development of the Islamic boarding school.
\end{abstract}

Keyword: development, economy, Islamic boarding school

\section{Abstrak}

Tulisan ini merupakan hasil penelitian terapan tentang pengembangan potensi ekonomi pesantren pada 5 pesantren di Lamongan Jawa Timur tahun 2010. Penelitian ini dilatarbelakangi oleh kenyatanan bahwa dalam konteks pengembangan ekonomi masyarakat, pesantren dihadapkan pada upaya peningkatan taraf hidup dan kesejehateraan masyarakat dalam bentuk kegiatan usaha yang dimulai dengan penelaahan potensi dan peluang usaha yang dimiliki, termasuk potensi SDM dengan melibatkan masyarakat setempat. Tujuan penelitian ini adalah membantu pesantren dalam mengembangkan potensi ekonomi melalui program pendampingan. Dalam penelitian ini dilakukan beberapa tahapan antara lain, studi kelayakan yang menetapkan 5 pondok pesantren sebagai pelaksana program, kegiatan orientasi yang difokuskan pada usaha pengembangan penggemukan sapi dan pemberian dana pengembangan dan replikasi, serta kegiatan supervisi, monitoring, evaluasi, dan refleksi demi tercapainya usaha pengembangan ekonomi pesantren. Hasilnya terdapat peningkatan mutu pengelolaan dan pengembangan ekonomi pesantren.

Kata Kunci: Pengembangan, Ekonomi, Pesantren

\section{PENDAHULUAN}

Pondok pesantren sebagai sebuah lembaga pendidikan Islam telah lama memainkan peran yang strategis di tengah-tengah kehidupan masyarakat dan bangsa Indonesia. Oleh karenanya sejak semula pesantren merupakan salah satu model pendidikan yang sudah lama mengakar dalam kehidupan masyarakat Indonesia. Bahkan, memiliki sifat dan karakteristiknya mampu menyesuaikan diri memenuhi

Naskah diterima 10 Januari 2013. Revisi pertama, 21 Februari 2013. Revisi kedua, 7 Maret 2013 dan revisi terahir 02 April 2013. 
tuntutan masyarakat. ${ }^{1}$ Pesantren juga menjadi lembaga pendidikan Islam pertama dan khas pribumi yang bertahan hingga kini. Ke-khasannya tidak saja karena keberadaannya yang sudah sangat lama, tetapi juga karena kultur/ tradisi dan jaringannya yang begitu luas. Lahirnya sistem pendidikan Islam di Indonesia sesungguhnya cikal bakalnya berasal dari pendidikan pesantren.

Pesantren didirikan oleh para ulama' untuk mendidik, membimbing dan memberdayakan santri dan masyarkat dalam aspek keagamaan, sosial-budaya, ekonomi, dan politik. Aspek-aspek yang menjadi bidang garapan pesantren ini sudah lama dikembangkan oleh para ulama dengan memperkuat potensi sumberdaya lokalnya sehingga hubungan-hubungan yang dijalankan pesantren sangat terkait dengan keberadaan masyarakat, pemerintah, dan pelaku bisnis. Tak heran jika pesantren memainkan peranan yang begitu besar dalam beberapa aspek kehidupan masyarakat.

Pengembangan beberapa aspek kehidupan masyarakat ini sesungguhnya merupakan cita-cita luhur para founding father pondok pesantren dalam membangun peradaban dan budaya yang unggul melalui pendidikan agama Islam di pesantren agar masyarakat dan bangsa ini bangkit dari keterpurukan bidang pendidikan maupun bidang yang lain, termasuk bidang ekonomi. Dalam hal ini pondok pesantren selain sebagai lembaga tafaqquhfiddin, juga merupakan tempat untuk menyiapkan kemandirian santri-santrinya, melalui upaya pengembangan ekonomi masyarakat.

Dalam konteks pengembangan ekonomi masyarakat, pesantren dihadapkan pada upaya peningkatan taraf hidup masyarakat dalam bentuk kegiatan usaha bersama masyarakat. Hal ini sesungguhnya telah lama menjadi karakteristik pesantren yang selalu mampu mandiri dan swadaya dalam kegiatan dakwah Islam di masyarakat, dan bekerjasama dengan

${ }^{1}$ Mujamil Qomar, (2006) Pesantren Dari Transformasi Metodologi menuju Demokratisasi Institusi (Jakarta: Erlangga,), h. 79 masyarakat dalam peningkatan kesejahteraan. (Sahal Mahfudh, 2007).

Terkait dengan pengembangan ekonomi pondok pesantren, maka patut kita telaah sejauh mana peran pondok pesantren dalam upaya meningkatkan taraf hidup (perekonomian) warga sekitar sebagai bagian dari perang melawan kemiskinan (jihad) karena kaum muslim di Indonesia sampai sekarang masih terpinggirkan. Konsep memerangi kemiskinan harus menambahkan dakwah bil lisan dan dakwah bil hal melalui upaya pengembangan ekonomi yang mampu menarik pasar. ${ }^{2}$

Kegiatan pengembangan ekonomi pesantren telah banyak dilakukan melalui penelitian partisipatif, diantaranya penelitian Puslitbang Pendidikan Agama dan Keagamaan, oleh Wahid Khozin, antara lain dalam penelitian menyebutkan bahwa keberhasilan pengembangan perikanan lele di pesantren Nurul Mursidah karena didukung oleh komitmen pimpinan dan komunitas pesantren yang cukup tinggi. Implementasi perikanan lele di pesantren $\mathrm{Nu}-$ rul Mursyidah merupakan hasil refleksi dari apa yang dilihat dan diperoleh dari pesantren karya nyata. Keberhasilan ini menjadi sebuah model pengembangan perikanan lele pondok pesantren. ${ }^{3}$

Sumber-sumber pendanaan bagi pengembangan pondok pesantren tidak saja berasal dari Departemen Agama, tetapi lebih ditekankan pada ikhtiar masing-masing pondok pesantren. Dahulu pendanaan itu dilakukan pemerintah dengan membantu memberikan ternak bagi pondok pesantren-pondok pesantren di Indonesia, namun dengan disertai motif politik. Perubahan akan lebih baik jika sebagian besar dimulai dari dalam pondok pesantren. Masing-masing pondok pesantren harus menelaah potensi-potensi dan peluang-peluang

${ }^{2}$ Sarwani, Penguatan Kelembagaan Ekonomi Pesantren, (makalah disampaikan pada orientasi program pengembangan potensi ekonomi pesantren, Maret 2010)

${ }^{3}$ Wahid Khozin, Pemberdayaan Ekonomi Pesantren: Studi Kasus Pesantren Nurul Mursyidah Pandeglang, dalam Edukasi Volume 9 nomor 1Januari April 2011, Halaman $4252-4273$. 
usaha yang dimiliki (SWOT - Strength, Weakness, Opportunity, Treaty) di lingkungan masing-masing termasuk potensi SDM dengan melibatkan warga sekitar. Dari sini menunjukkan pentingnya pengembangan ekonomi pondok pesantren dengan penelitian partisipatif. Penelitian partisipatif tentang pengembangan ekonomi pondok pesantren kali ini lebih pada program penggemukan sapi, melalui upaya mengaktualisasikan potensi ekonomi yang dimiliki menuju kemandirian ekonomi pesantren.

\section{Permasalahan}

Berdasarkan latar belakang di atas, permasalahan dalam penelitian ini adalah: bagaimanakah membangkitkan jiwa interpreneur di pesantren melalui program penggemukan sapi, yang merupakan upaya mengaktualisasikan potensi yang sudah dimiliki pesantren, dan pentingnya pesantren yang mandiri sebagai suatu sistem yang mengorganisir diri mereka sendiri .

\section{Tujuan Penelitian}

Penelitian ini bertujuan untuk:

1. Mengembangkan ekonomi pondok pesantren melalui upaya mengaktualisasikan potensi ekonomi yang dimiliki;

2. Mengembangkan ekonomi pondok pesantren melalui program pendampingan;

3. Membangkitkan jiwa interpreneur pondok pesantren menuju kemandirian ekonomi.

\section{KERANGKA TEORETIK}

\section{Pengembangan Ekonomi Pesantren}

Pengembangan menurut para ahli berarti uapaya yang dilakukan secara sistematis sejak dari perencanaan, pelaksanaan dan evaluasi program. Pengembangan dalam kontek penelitian ini lebih dipahami sebagai kegiatan pemberdayaan masyarakat. Dalam Ensiklopedia bebas Wikipedia bahasa Indonesia, pemberda- yaan masyarakat adalah proses pembangunan di mana masyarakat berinisiatif untuk memulai proses kegiatan sosial untuk memperbaiki situasi dan kondisi diri sendiri ${ }^{[1]}$. Pemberdayaan masyarakat hanya bisa terjadi apabila warganya ikut berpartisipasi. ${ }^{4}$ Menurut Departemen Pekerjaan Umum, pemberdayaan masyarakat dapat diartikan sebagai suatu upaya untuk memulihkan atau meningkatkan keberdayaan suatu komunitas agar mampu berbuat sesuai dengan harkat dan martabat mereka dalam melaksanakan hak - hak dan tanggung jawab mereka sebagai komunitas manusia dan warga negara. ${ }^{5}$

Afrizal menyatakan bahwa pemberdayaan masyarakat adalah memampukan dan memandirikan masyarakat, hingga muncul perubahan yang lebih efektif dan efisient. Meskipun pemberdayaan masyarakat bukan semata-mata sebuah konsep ekonomi, dari sudut pandang kita pemberdayaan secara implisit mengandung arti menegakkan demokrasi ekonomi dimana kegiatan ekonomi berlangsung dari rakyat oleh rakyat dan untuk rakyat. Konsep ini menyangkut penguasan teknologi, pemilikan modal, dan akses ke pasar dan kedalam sumber-sumber informasi, serta keterampilan manajemen. Agar demokrasi ekonomi dapat berjalan, maka aspirasi masyarakat tertampung harus diterjemahkan menjadi rumusan-rumusan yang nyata. ${ }^{6}$ Pengertian Pemberdayaan Masyarakat sebenarnya mengacu pada kata "Empowerment", yaitu sebagai upaya mengaktualisasikan potensi yang sudah

${ }^{4}$ http://id.wikipedia.org/wiki/Pemberdayaan_masyarakat, Ensiklopedia bebas Wikipedia bahasa Indonesia, devinisi ini diambil dari James A. Christenson \& Jerry W. Robinson, Jr Ames (edited): Iowa State University Press, 1989, Community development in perspective.

${ }^{5}$ Departemen Pekerjaan Umum, Direktorat Jendral Cipta Karya, Modul Dasar Pemberdayaan Masyarakat, PNPM Mandiri, http://id.search.yahoo.com/ search; _ylt=A0oGkmFnMHpRWXCANRPLQwx.?p=p emberdayaan +masyarakat\&ei=UTF-8\&fr=yfp-t-713s\&xargs $=0 \&$ pstart $=1 \& b=11$

${ }^{6}$ Afrizal Woyla Saputra Zaini, Pembangunan Pemberdayaan Masyarakat, 20 Februari 2011, http://afrizalwszaini.wordpress.com/2011/02/20. 
dimiliki oleh masyarakat.? Begitu pula dalam pengembangan ekonomi pesantren maka usaha penggemukan sapi juga merupakan upaya mengaktualisasikan potensi yang sudah dimiliki oleh pesantren. Jadi pendekatan pemberdayaan ekonomi masyarakat dalam kontek pengembangan ekonomi pesantren, khususnya program penggemukan sapi pesantren adalah penekanan pada pentingnya pesantren yang mandiri dalam program penggemukan sapi, sebagai suatu sistem yang mengorganisir diri mereka sendiri.

Dalam upaya pengembangan ekonomi pesantren, diperlukan pendampingan, yang berperan untuk memberikan berbagai masukan dan pertimbangan yang diperlukan oleh kelompok pengelola penggemukan sapi dalam menghadapi masalah. Pendamping tidak memutuskan apa yang perlu dilakukan, akan tetapi pengelolalah yang nantinya membuat keputusan. Pendamping juga memiliki peran memberikan berbagai kemampuan dasar yang diperlukan oleh kelompok pengelola seperti mengelola rapat, pembukuan, administrasi, memecahkan masalah, mengambil keputusan dan sebagainya. Di samping itu, pendamping berperan sebagai penghubung pesantren dengan lembaga-lembaga yang terkait (stakeholder) dan diperlukan bagi pengembangan ekonomi pesantren.

Pada dasarnya, pendampingan merupakan upaya untuk menyertakan masyarakat dalam mengembangkan berbagai potensi sehingga mampu mencapai kualitas kehidupan yang lebih baik. Selain itu diarahkan untuk memfasilitasi proses pengambilan keputusan yang terkait dengan kebutuhan masyarakat, membangun kemampuan dalam meningkatkan pendapatan, melaksanakan usaha yang berskala bisnis serta mengembangkan perencanaan dan pelaksanaan kegiatan partisipatif. ${ }^{8}$

${ }^{7}$ http://tesisdisertasi.blogspot.com/2010/03/ pengertian-pemberdayaan-masyarakat.html.

${ }^{8}$ http:// Green Blue-Phinisi.Blogspot.com/2009/03/ Upaya Pemberdayaan Masyarakat, di-bidang.html
Prinsip-prinsip pendampingan dalam upaya pengembangan ekonomi masyarakat meliputi:

a. Prinsip Spasial Lokal. Penguasaan dan pemahaman terhadap ruang, kondisi, potensi dan bahasa lokal dalam pemberdayaan masyarakat.

b. Prinsip Berkelompok. Kelompok tumbuh dari, oleh dan untuk kepentingan masyarakat. Selain dengan anggota kelompoknya sendiri, kerjasama juga dikembangkan antara kelompok dan mitra kerja lainnya agar usaha mereka berkembang, meningkatkan pendapatan dan kesejahteraan serta mampu membentuk kelembagaan ekonomi.

c. Prinsip Keberlanjutan. Seluruh kegiatan penumbuhan dan pengembangan diorientasikan pada terciptanya sistem dan mekanisme yang mendukung pemberdayaan masyarakat secara berkelanjutan. Berbagai kegiatan yang dilakukan merupakan kegiatan yang memiliki potensi berlanjut di kemudian hari.

d. Prinsip Kemandirian. Masyarakat diberi motivasi dan dorongan untuk berusaha atas dasar kemauan dan kemampuan mereka sendiri dan tidak selalu tergantung pada bantuan dari luar.

e. Prinsip Kesatuan Keluarga. Masyarakat tumbuh dan berkembang sebagai satu kesatuan keluarga yang utuh. Kepala keluarga beserta anggota keluarganya merupakan pemacu dan pemicu kemajuan usaha. Prinsip ini menuntut para pendamping untuk memberdayakan seluruh anggota keluarga masyarakat berperan serta dalam meningkatkan pendapatan dan kesejahteraan.

f. Prinsip Belajar Menemukan Sendiri. Kelompok dalam masyarakat tumbuh dan berkembang atas dasar kemauan dan kemampuan mereka untuk belajar menemukan sendiri apa yang mereka butuhkan dan apa yang akan mereka kembangkan, 
termasuk upaya untuk mengubah penghidupan dan kehidupannya. ${ }^{9}$

Dalam upaya pengembangan ekonomi pesantren melalui usaha penggemukan sapi, maka berbagai pertimbangan terkait dengan pemaknaan dari pemberdayaan ekonomi masyarakat dan prinsip-prinsip pendampingan haruslah diperhatikan. Hal-hal yang menjadi pertimbangan terkait dengan program penggemukan sapi pesantren, antara lain potensi ekonomi pesantren yang lebih dimaknai sebagai asset dan kekayaan lahan yang mesti dimiliki, usaha penggemukan sapi yang memang telah lama dilakukan pesantren sebagai bentuk dan jenis kegiatan ekonomi yang selama ini dikembangkan di pesantren. Hal itu merupakan modal ekonomi yang perlu dipertimbangkan dalam rangka pengembangan ekonomi melalui program pendampingan. Karena program pendampingan pada dasarnya adalah lebih banyak meningkatkan efektifitas dan produktifitas kegiatan ekonomi yang sudah ada, dengan proses replikasi dan penggunaan teknologi.

\section{Supervisi monitoring;}

Supervisi dan monitoring merupakan kegiatan yang sangat penting dilakukan. Supervisi dan monitoring memiliki makna yang berbeda, walaupun dalam pelaksanaannya seringkali dilakukan secara bersamaan. Supervisi merupakan istilah yang menunjuk pada suatu pekerjaan pengawasan tetapi sifatnya lebih "human, manusiawi". Di dalam kegiatan supervisi, pelaksanaan bukan mencari-cari kesalahan atau kekurangan, tetapi lebih banyak mengandung unsur pembinaan, agar pekerjaan yang disupervisi diketahui kekurangannya. ${ }^{10}$ Supervisi yang dimaksud di sini adalah bantuan, layanan, jasa, nasihat, motivasi yang diberikan tim supervisor, dengan tujuan agar para pengelola

'Ibid, http:// Green Blue-Phinisi.Blogspot. com/2009/03/Upaya Pemberdayaan Masyarakat, di-bidang.html

${ }^{10} \mathrm{http}: / / \mathrm{www}$.pengertiandefinisi. com/2012/02/pengertian-supervisi.html, Monday, February 27, 2012 program pemberdayaan ekonomi di pesantren mampu melaksanakan programnya sesuai yang ditetapkan. Dengan kata lain, supervisi dimaksud sebagai pemberian bantuan, dorongan untuk peningkatan kemampuan profesional pengelola program di lapangan dalam upaya pewujudan tujuan program.

Supervisi bukan bertujuan untuk untuk memberikan vonis tentang kemampuan seseorang atau mengontrol pekerjaannya, tetapi lebih mengarah kepada bentuk kerja sama antara supervisor dengan yang disupervisi. ${ }^{11}$ Supervisi berorientasi pada program-program bimbingan kepada pihak yang disupervisi, sesuai dengan bidang tugas masing-masing dalam rangka pencapaian tujuan program yang telah ditetapkan. Program-program bimbingan tersebut seperti bimbingan dan pengarahan dalam penyusunan rencana kegiatan, pengorganisasian, pelaksanaan, koordinasi dan penilaian kegiatan.

Adapun Monitoring pada dasarnya adalah kegiatan untuk melakukan penilaian terhadap implementasi riset aksi program pemberdayaan ekonomi pesantren. Kegiatan monitoring merupakan proses rutin pengumpulan data dan pengukuran kemajuan atas objektif program. Monitoring juga merupakan pemantauan yang dapat dijelaskan sebagai kesadaran tentang apa yang ingin diketahui, pemantauan berkadar tingkat tinggi dilakukan agar dapat membuat pengukuran melalui waktu yang menunjukkan pergerakan ke arah tujuan atau menjauh dari itu. ${ }^{12}$

Monitoring dilakukan untuk memantau perubahan, yang befocus pada proses dan keluaran. Monitoring juga dilakukan untuk memeriksa terhadap proses berikut objek atau untuk mengevaluasi kondisi atau kemajuan menuju tujuan hasil pengelolaan program. Kegiatan monitoring dilakukan ketika sebuah program

${ }^{11}$ http://www.lebahndut.net/2012/11/ apa-itu-supervisi-definisi-pengertian-supervisi. html, di ambil dari buku "Effective Supervision" karya Wayne K. Hoy dan Patrick B. Forsyth.

${ }^{12}$ Indra K.Nasution, (2009), menjembatani penelitian_dan_kebijakan, http://id.wikipedia .org/ wiki/Monitoring 
sedang diimplementasikan. Dalam monitoring dilakukan pengumpulan dan analisis informasi secara sistematis mengenai perkembangan program/kegiatan. Tujuannya adalah memperbaiki efisiensi dan efektivitas program/kegiatan atau organisasi. Monitoring didasarkan pada satuan target dan aktivitas yang direncanakan. Monitoring dilakukan untuk membantu pekerjaan pengelola program agar tetap di dalam jalur yang tepat, dan memberi tahu manajemen jika terdapat penyimpangan atau kesalahan serta ingin mengetahui kemandirian pengelola program dalam mengatasi persoalan program. Di samping itu memberi tahu apakah sumberdaya mencukupi dan digunakan secara tepat, dan kegiatan berjalan sesuai rencana. ${ }^{13}$ Jadi dapat pahami bahwa monitoring dilaksanakan dalam rangka mengetahui apakah program berjalan sesuai rencana atau tujuan, mengetahui hambatan-hambatan yang diala$\mathrm{mi}$, serta bagaimana pengelola program dalam mengatasi hambatan tersebut.

Dalam monitoring peneliti/fasilitator meminta tim pengelola program untuk memberikan informasi yang jelas tentang pencapaian tarjet pengelolaan program yang telah dilakukan, termasuk menyebutkan kendala-kendala yang terjadi di lapangan terkait dengan pelaksanaan program. Untuk selanjutnya, apa yang perlu diperbaiki? Pertanyaan ini memunculkan refleksi atas keberhasilan dan kegagalan sepanjang pelaksanaan program, kegiatan, acara atau tugas. Pertanyaan 'mengapa' dapat memberikan pemahaman tentang akar penyebab kegagalan dan keberhasilan. Apa yang berhasil? Apa yang tidak? Mengapa? Pertanyaan-pertanyaan tersebut memberikan pemahaman bersama atas hal-hal yang tengah dikaji. Eksplorasi lebih mendalam harus dilakukan jika terjadi penyimpangan dari rencana semula. Apa yang seharusnya terjadi? Apa yang sebenarnya terjadi? Mengapa terjadi perbedaan? Dst.

Tujuan supervisi monitoring adalah: (1) menjaga agar program/kegiatan yang sedang

\footnotetext{
${ }^{13}$ Indra K.Nasution, (2009), menjembatani penelitian_dan_kebijakan, Http://www.smeru.or.id/ reporttraining
}

diimplementasikan sesuai dengan tujuan dan sasaran, (2) menemukan kesalahan sedini mungkin sehingga mengurangi resiko yang lebih besar, dan (3) melakukan tindakan modifikasi terhadap program/kegiatan apabila hasil superfisi dan monitoring mengharuskan untuk itu. Adapun yang dilakukan dalam kegiatan supervisi monitoring adalah mengembangkan indikator efisiensi, efektivitas, dan dampak program, membangun sistem untuk mengumpulkan data dan informasi yang berhubungan dengan indikator, menganalisis data dan informasi, dan menggunakan informasi untuk perbaikan program.

Kegiatan ini dilakukan untuk mengamati secara langsung proses pelaksanaan kegiatan penguatan dan pengembangan ekonomi pesantren melalui pendampingan. Kegiatan ini juga dilakukan untuk mendeskripsikan kegiatan penguatan dan pengembangan ekonomi pesantren yang dilaksanakan, hambatan-hambatan yang ditemui, serta bagaimana mengatasi hambatan tersebut. Hasil monitoring digunakan sebagai informasi yang dapat digunakan untuk memberikan masukan dalam perbaikan (supervisi) terhadap pengelola kegiatan penguatan dan pengembangan ekonomi pesantren.

Ruang lingkup supervisi dan monitoring meliputi pemanfaatan dana pengembangan program penggemukan sapi, sosialisasi program, pelaksanaan program, kemampuan kepemimpinan dan manajerial pengelola program, dan perbaikan manajemen program penggemukan sapi. Kegiatan supervisi dan monitoring dilaksanakan oleh pelaksana program tingkat pusat di lingkungan Puslitbang pendidikan Agama dan Keagamaan Balitbang dan Diklat Kementrian Agama. Sasaran supervisi dan monitoring adalah pengurus pengelola program penggemukan sapi, pimpinan pesantren, pengurus pesantren, dan tokoh masyarakat di lingkungan pesantren setempat.

Pendekatan Supervisi dan Monitoring dilakukan oleh tim pusat dan daerah dalam kerangka hubungan kerabat kerja profesional, dalam arti posisi tim pusat dan daerah 
adalah sejajar, dan bersifar mitra, yang secara bersama-sama menganalisis masalah, mencari alternatif pemecahan, dan sekaligus mengadakan perbaikan/pemecahan masalah. Supervisi dilaksanakan dengan cara kunjungan langsung ke lapangan untuk mengamati pelaksanaan program, mempelajari dokumen tertulis (laporan, data dan dokumen lainnya), rapat pertemuan reguler untuk membicarakan masalah dalam pelaksanaan program, dan pertemuan individual antara yang disupervisi dengan supervisor.

\section{Metode Penelitian}

Penelitian ini diselenggarakan pada bulan Februari - Nopember 2010. Adapun lokasi penelitian adalah di 5 pondok pesantren Kabupaten Lamongan Jawa Timur. Adapun sifat penelitian ini adalah untuk pengembangan ekonomi Pondok Pesantren yang telah memiliki usaha di bidang ekonomi, khususnya penggemukan sapi.

Metode yang digunakan dalam penelitian ini adalah penelitian partisipatif. Pada hakekatnya yang menjadi subyek dari penelitian ini adalah pesantren itu sendiri. Pesantren dalam hal ini penting dibangkitkan kesadarannya untuk mengaktualisasikan potensi ekonomi yang sudah dimiliki. Namun, dengan segala keterbatasan yang dimiliki pesantren, baik pengetahuan, ketrampilan, informasi-informasi pengembangan ekonominya dan sebagainya, maka potensi ekonomi khususnya penggemukan sapi belum dapat dikembangkan. Oleh karena itu metode penelitian yang tepat digunakan adalah action research.

\section{HASIL DAN PEMBAHASAN}

Untuk mengungkapkan penelitian tentang program pengembangan ekonomi pesantren, melalui program penggemukan sapi, maka dalam penelitian ini dilaksanakan beberapa tahapan kegiatan, yaitu studi kelayakan, kegiatan orientasi, pemberian dana pengembangan, penerapan dan upaya replikasi program, supervisi monitoring, evaluasi, refleksi dan hasil pencapaian program. Adapun secara rinci dapat dijelaskan sebagai berikut:

\section{Studi Kelayakan}

Pemilihan pesantren untuk menetapkan menjadi lembaga yang akan melakukan program penguatan dan pengembangan ekonomi ini dilakukan dengan studi kelayakan. Studi kelayakan dilakukan sebagai langkah awal untuk memilih dan menetapkan pondok pesantren dimaksud. Untuk menentukan tingkat kelayakan dilihat dan diidentifikasi 10 calon pondok pesantren berdasarkan informasi dari Kasi Pondok Pesantren Kementrian Agama Kabupaten Lamongan, yang kemudian dilihat langsung oleh peneliti di lokasi pesantren dengan melihat kondisi pesantren berkenaan dengan:

a. Dukungan pimpinan pesantren berkenaan dengan kesediaan melaksanaan program pengembangan potensi ekonomi di pondok pesantrennya.

b. Sistem pesantren dalam pengembangan usaha bidang ekonomi (adanya kepedulian dan dukungan input, proses dan produk untuk pengembangan usaha bidang ekonomi)

c. Potensi SDM dan pemanfaatan resources (Pondok Pesantren memiliki tenaga-tenaga yang peduli dalam pengembangan usaha bidang ekonomi dan kemampuannya memanfaatkan resources pesantren).

d. Kondisi geografis mendukung pelaksanaan program pengembangan potensi ekonomi pondok pesantren.

e. Kondisi sosiokultur pesantren baik internal maupun eksternal (budaya pesantren dan masyarakat dapat memperkokoh pengembangan usaha bidang ekonomi)

f. Bidang Usaha Perekonomian dan peluangnya untuk dikembangkan (Pondok Pesantren telah memiliki usaha di bidang ekonomi dan memungkinkan untuk dapat dikembangkan) 
g. Kondisi sarana dan prasarana (keadaan sarana dan prasarana usaha ekonomi).

Hasil studi kelayakan tergambar masingmasing pesantren berkenaan tentang; profil pesantren sasaran penelitian, peta pengembangan potensi ekonomi pesantren, dan peta kesiapan pesantren untuk melaksanakan program pengembangan ekonomi. Berdasarkan hal tersebut kemudian diranking dan ditetapkan 5 pondok pesantren yang melaksanakan penguatan dan pengembangan ekonomi pesantren, yaitu program penggemukan sapi . Adapun 5 pondok pesantren tersebut adalah:

Tabel 1.5 pondok pesantren

\begin{tabular}{|c|l|l|}
\hline No & \multicolumn{1}{|c|}{ Nama PP } & \multicolumn{1}{|c|}{ Alamat } \\
\hline 1. & $\begin{array}{l}\text { PONDOK PESANTREN AL-ISLAM } \\
\text { TENGGULUN }\end{array}$ & $\begin{array}{l}\text { Ds. Tenggulun RT 02 / RW 01 Soloku- } \\
\text { ro Lamongan }\end{array}$ \\
\hline 2. & $\begin{array}{l}\text { PONDOK PESANTREN MAZRO- } \\
\text { ATUL FATAH }\end{array}$ & $\begin{array}{l}\text { Jl. KH Abd Fatah Ds. Siman Kecamat- } \\
\text { an Sekaran Lamongan }\end{array}$ \\
\hline 3. & PONDOK PESANTREN AL-JIHAD & $\begin{array}{l}\text { Banjarwati RT. 003 / RW 001 Kelu- } \\
\text { rahan Banjarwati Kecamatan Paci } \\
\text { Lamongan }\end{array}$ \\
\hline 4. & $\begin{array}{l}\text { PONDOK PESANTREN RAUDLA- } \\
\text { TUL MUTA'LIMIN }\end{array}$ & $\begin{array}{l}\text { Jl. Raya Babat Surabaya Ds Tegalrejo } \\
\text { Datinawon Lamongan }\end{array}$ \\
\hline 5. & $\begin{array}{l}\text { YAYASAN PONDOK PESANTREN } \\
\text { NURUL JAMI'AL-KAUTSAR }\end{array}$ & $\begin{array}{l}\text { Ds. Manyar Kecamatan Sekaran } \\
\text { Lamongan }\end{array}$ \\
\hline
\end{tabular}

\section{Kegiatan Orientasi}

Kegiatan orientasi ini diselenggarakan pada bulan Maret 2010 selama 5 (lima) hari, yaitu pada tanggal 11 - 15 Maret 2010. Tempat orientasi di pusatkan di Pondok Pesantren Mazroatul Mutaalimin Kabupaten Lamongan. Kegiatan ini melibatkan sebanyak 5 Lembaga pondok pesantren, dengan masing-masing pondok pesantren mengirimkan 5 peserta dari pengelola bidang usaha ekonomi pesantren.

Kegiatan orientasi ini bertujuan untuk memberikan bekal pengetahuan dan ketrampilan kepada peserta orientasi tentang konsep, bentuk dan materi penguatan dan pengembangan ekonomi pondok pesantren, utamanta program penggemukan sapi. Hasil yang diharapkan dari orientasi ini adalah peserta dapat memahami konsep, bentuk dan materi program penggemukan sapi serta penerapannya dalam usaha penggemukan sapi secara professional.
Untuk mencapai tujuan orientasi sebagaiman disebutkan di atas, dalam orientasi ini disampaiakan materi-materi tentang: (1) Penguatan dan pengembangan usaha ekonomi pesantren, dengan nara sumber $\mathrm{H}$. Abdullah Sarwani, (2) Manajemen usaha penggemukan sapi pondok pesantren Oleh: Drs. Wardoyo (Dinas Peternakan Lamongan), (3) Manajemen kandang, manajemen produksi dan manajemen penyakit Oleh: . Dr.h. Joko Legowo, (4) Manajemen pakan dan manajemen reproduksi oleh Dr.h. Heri Agus Darnadi, dan (5) Klinik perawatan umum dan pengelolaan limbah dan praktek manajemen kandang, produksi pakan, reproduksi, penyakit, perawatan umum, dan pengolahan limbah oleh Dr.h. Nusdianto Triakoso, dan terakhir Melakukan Kunjungan Ke Lokasi Binaan Dinas Peternakan Lamongan yang didampingi oleh Dr.h. Joko Legowo, Dr.h. Nusdianto Triakoso, Dr.h. Heri Agus Darnadi dan Drs. Wardoyo.

Dengan kegiatan orientasi maka para peserta yang semua adalah pengurus pengelola usaha penggemukan sapi pada lima pondok pesantren menjadi lebih memahami bagaimana cara mengelola penggemukan sapi secara professional. Pada akhir kegiatan orientasi mereka membuat rancangan program penggemukan sapi dan dipresentasikan di depan para narasumber dan peserta. Untuk selanjutnya mereka setelah pulang ke pesantren diwajibkan melakukan beberapa kegiatan, yaitu: (1) melaporkan hasil kegiatan orientasi kepada pimpinan pondok, (2) mensosialisasikan program penggemukan sapi secara professional, (3) rapat penentuan pengembangan ekonomi pondok yang akan digarap, terkait dengan penggemukan sapi dan anggaran yang diperlukan dalam usaha tersebut, (4) pelaksanaan hasil dari keputusan rapat berkenaan dengan usaha penggemukan sapi pesantren, (5) melaksanakan program dan upaya replikasi, dan (6) melakukan pelaporan program dan pertanggungjawaban keuangan. 


\section{Pemberian Dana Pengembangan}

Pemberian dana pengembangan tentang usaha penggemukan sapi dilakukan setelah mereka memperoleh pembekalan melalui kegiatan orientasi, dan mengajukan rancangan program penggemukan sapi dengan menyertakan susunan kepengurusan lembaga ekonomi yang menangani kegiatan program tersebut.

Dengan dasar hal tersebut pengurus program tersebut memperoleh dana pengembangan. Pemberian dana pengembangan ini diberikan kepada mereka melalui transfer uang ATM ke nomor rekening Bank BRI. Untuk selanjutnya mereka pengurus mengirimkan tanda bukti berupa print out dan pembelanjaan dana pengembangan tersebut kepada Puslitbang Panda dan Keagamaaaan sebagai penyelenggara penelitian tersebut.

Pada umumnya para pengelola usaha penggemukan sapi pesantren yang menempatkan bantuan dana sebagai suplemen karena di pesantren tersebut telah berjalan program yang sama. Kegiatan ekonomi yang ada kemudian ditunjang dengan dana bantuan, untuk memperluas, menambah dan mengembangkan apa yang sudah ada. Dana pengembangan ratarata mereka digunakan untuk pembelian sapi. Adapun terkait keperluan kandang, pakan, obat-obatan dan lain-lain merupakan swadaya pesantren, karena pesantren sebelumnya telah melakukan usaha penggemukan sapi hanya saja kemudian dilakukan pengembangan dengan upaya pembekalan, replikasi/penularan dan pelaksanaan usaha secara professional.

Selama ini usaha penggemukan sapi pesantren sasaran, telah lama dilakukan dengan membangun kemitraan dengan masyarakat sekitar. Usaha penggemukan sapi pesantren itu terbukti telah memberikan keuntungan finansial, namun hal ini membutuhkan biaya besar. Oleh karena itu dalam usaha penggemukan sapi pesantren, dana pengembangan sangat diperlukan. Secara umum pesantren sasaran sangat memerlukan dana pengembangan untuk mempercepat pengembangan usahanya, sampai peantren yang bersangkutan memun- gkinkan melakukan kegiatan usaha penggemukan sapi secara mandiri dan professional. Kecuali pesantren Roudlotul Mutaalimin, yang sejak semula telah mampu mengembangkan usaha penggemukan sapi secara mandiri.

\section{Penerapan dan Upaya Replikasi Program}

Perlu dijelaskan di sini bahwa penelitian terapan tentang program pengembangan ekonomi pesantren, khususnya usaha penggemukan sapi pesantren memiliki peran ganda yaitu memberikan bekal ketrampilan pesantren dan sekaligus memberikan penguatan basis ekonomi dan kemandirian pesantren. Kedua hal tersebut merupakan wujud sistem pendidikan pesantren yang bermutu, relevan dan memiliki daya saing dan sekaligus memperkuat jatidiri komunitas pesantren yang mandiri. Itulah sebabnya banyak analisis menyatakan pesantren memiliki peran agent perubahan sosial khususnya melalui usaha pengembangan ekonomi yang pada akhirnya akan menyentuh masyarakat di sekitar pesantren.

Usaha pengembangan ekonomi khususnya terkait program penggemukan sapi pesantren yang dilakukan pada lima pesantren di daerah lamongan, dengan pertimbangan karena lingkungan masing-masing sekitar pesantren sangat mendukung untuk mengembangkan usaha tersebut. Di daerah Lamongan umumnya memang merupakan daerah areal peternakan, khususnya penggemukan sapi potong. Penggemukan sapi pesantren di Lamongan bahkan telah melakukan pemanfaatan kotoran sapi yang dapat dikelola sebagai biogas. Kegiatan pemanfaatan kotoran untuk biogas ini sangat mendukung progam pemerintah dalam penghematan energi. Usaha ini juga termasuk pemaksimalan pengelolaan sumberdaya manusia yang terampil dengan penguasaan teknologi yang memadai. Di beberapa pesantren yang terlibat dalam program penggemukan sapi ini memang sangat mendukung secara geografis dalam usaha tersebut, diantaranya di pesantren telah tersedia lahan yang cukup untuk usaha tersebut, yaitu lahan untuk pembangunan kandang maupun untuk 
pengembangan tanaman pakan ternak. Di samping itu terdapat dukungan kebijakan pemerintah untuk pengembangan sektor agrobisnis khususya bidang peternakan dan memiliki tingkat kelayakan ekonomi dan sosial yang signifikan.

Kegiatan Penggemukan sapi pesantren merupakan salah satu kegiatan ekonomi yang menghasilkan. Sebenarnya kegiatan ini merupakan kerjasama pihak pesantren dengan masyarakat sekitar pesantren. Dalam pelaksanaan usaha penggemukan sapi pesantren melibatkan sebagian wali santri yang tidak mampu untuk mengelola kegiatan tersebut. Dengan demikian kegitan ini dapat mempererat hubungan pesantren dengan wali santri. Di samping itu hasil upah dari kegiatan ini dapat meringankan biaya anaknya nyantri di pesantren karena memang kemampuan ekonomi wali santri relatif rendah.

Menurut para pengurus pengelola usaha penggemukan sapi pesantren, bahwa dengan program penggemukan sapi pesantren dari Badan Litbang dan Diklat Kementrian Agama dapat memicu untuk (1) semakin terciptanya pemberdayaan ekonomi pesantren, (2) munculnya wirausahawan di pondok pesantren, (3) adanya pemberdayaan masyarakat sekitar dan wali santri pondok pesantren, dan (4) semakin terwujudnya silaturrohim pesantren dengan wali santri.

Proses penerapan usaha penggemukan sapi pesantren dari ilmu-ilmu yang diperoleh dalam kegiatan orientasi ke 5 pesantren di Lamongan dilakukan dengan baik. Program yang diajarkan dalam kegiatan orientasi diterapkan di 5 pesantren dengan memperhatikan karakteristik daerah tentunya.

Ada beberapa hal penting yang dapat diambil dari penerapan usaha penggemukan sapi pesantren yaitu dari segi perencanaan, pelaksanaan dan evaluasi. Menurut sebagian pengurus pengelola penggemukan sapi pesantren, bahwa mereka merasa banyak mengalami kemajuan dalam pengelolaan penggemukan sapi setelah adanya kegiatan orientasi. Diantara hasil yang telah didapat adalah sistem penge- lolaan secara profesional yang sebelumnya kurang diperhatikan, menjadi diperhatikan. Perbandingan pemberian pakan yang sebelunya belum diperhatikan (pakan seadanya), menjadi sangat diperhatikan. Pencegahan dan pengobatan penyakit yang kurang dilakukan, menjadi adanya pencegahan dan pengobatan penyekit dilakukan dengan berbagai pendekatan.

Di salah satu pesantren di luar sasaran program ini yaitu Pesantren Sunan Drajat Lamongan yang telah lebih maju dalam berbagai usaha ekonomi pesantren, termasuk penggemukan sapi. Ke lima pesantren sasaran program banyak belajar dan melakukan penularan apa yang sudah dilakukan oleh pesantren Sunan Drajat. Di samping itu kelima pesantren itu membentuk forum komunikasi untuk membangun jaringan dan saling memberikan problem solving terhadap usaha penggemukan sapi pesantern. Dengan cara seperti inilah mereka melakukan upaya efektivitas usaha penggemukan sapi pesantren. Walhasil program penggemukan sapi pada lima pesantren telah menjadi kegiatan ekonomi yang menghasilkan.

Dalam kegiatan pengembangan potensi ekonomi pesantren khususnya program penggemukan sapi pesantren ini banyak faktor pendukungnya meskipun tidak sedikit ada hambatan. Namun dengan pengembangan ekonomi di pondok pesantren, ke depan pondok pesantren menjadi sebuah lembaga yang banyak diminati masyarakat karena di dalamnya tidak hanya kegiatan yang bersifat rohani saja tapi dibina dalam persoalan ekonominya.

\section{Supervisi Monitoring}

Kegiatan ini dilakukan untuk mengamati secara langsung proses pelaksanaan kegiatan penguatan dan pengembangan ekonomi pesantren melalui pendampingan. Kegiatan ini juga dilakukan untuk mendeskripsikan kegiatan pengembangan potensi ekonomi pesantren yang dilaksanakan khususnya usaha penggemukan sapi pesantren, hambatan-hambatan yang ditemui, serta bagaimana mengatasi hambatan tersebut. Hasil supervisi monito- 
ring digunakan sebagai informasi yang dapat digunakan untuk memberikan masukan dalam perbaikan (supervisi) terhadap pengelola kegiatan penguatan dan pengembangan ekonomi pesantren.

Program penguatan dan pengembangan potensi ekonomi pesantren pada dasarnya merupakan proses replikasi atau penularan keberhasilan suatu pesantren dalam mengembangakan kegiatan ekonomi kepada pesantren lain yang memiliki potensi ekonomi, SDM dan dukungan pimpinan pesantren yang tinggi. Pendampingan dimulai dari kegiatan orientasi berbasis praktek, pemberian dana pengembangan ekonomi, dan proses penularan atau replikasi, serta bantuan supervisi.

Dengan adanya program pengutan dan pengembangan potensi ekonomi pesantren ini menjadi bekal bagi pesantren untuk dapat lebih mengembangkan potensi-potensi yang ada di masing-masing pondok pesantren. $\mathrm{Pe}-$ manfaatan dana pengembangan tampak lebih diarahkan pada pembelian sapi, sedangkan untuk kandang dll lebih pada swadaya pesantren itu sendiri. Dari hasil supervise monitoring, ketika itu sapi yang baru dibeli sekitar satu bulan, tampak sehat dan ada kenaikan berat badan sapi.

Semangat pesantren dalam mengembangakan kegiatan ekonominya, bahkan pesantren tidak sering ingin mengandalkan bantuan dari pemerintah, tetapi dengan pembangunan ekonomi pesantren maka pesantren dapat membangun pondoknya dengan ekonominya sendiri.

Berkaitan dengan implementasi program penguatan dan pengembangan potensi ekonomi pesantren, para pengurus sebagai pengelola program penggemukan sapi pada pesantren masing masing sebagian besar telah memahami materi program penggemukan sapi, walaupun sebagian dari mereka masih melakukan konsultasi kepada yang lebih tahu. Di sini menunjukkan antara materi orientasi dengan pekerjaan sehari hari penggemukan sapi sudah match.
Dari semua materi orientasi yang diberikan sebagian besar pengelola penggemukan sapi sudah dapat melaksankan secara maksimal. Namun ada beberapa materi yang belum bias dilaksanakan misalnya pembuatan bogasi peternakan sapi karena keterbatasan atau tidak adanya tempat untuk pembuatannya.

Untuk sarana dan prasarana penggemukan sapi rata-rata sudah tersedia, namun sebenarnya masih membutuhkan penambahan dan penyempurnaan. Berkaitan dengan ketenagaan, dengan modal pengalaman sendiri dan hasil orientasi maka kesiapan tenaga di alapangan sudah dapat dianggap cukup memadai. Jenis ketenagaan di lapangan terdiri dari tenaga administrasi, tenaga lapangan, dan penanggung jawab.

Dari segi pembukuan, masih belum dilakukan secara professional. Misalnya proses penggemukan dalam perkembangannya belum dimasukkan dalam laporan pembukuan, ini menunjukkan sikap yang kurang teliti. Kemudian belum dibuat rincian/analisa usaha penggemukan sapi yang telah dilaksanakan.

Dari hasil supervisi monitoring ini digunakan sebagai informasi dan masukan perbaikan (supervisi) terhadap pengelola kegiatan penguatan dan pengembangan ekonomi pesantren. Di samping itu dalam kegiatan supervisi monitoring ini juga diinformasikan tentang akan dilaksankan program evaluasi pada akhir studi, yang di dalamnya dilakukan seminar pertanggunggung jawaban program penguatan dan pengembangan ekonomi pesantren oleh masing-masing pengelola program penggemukan sapi.

\section{Refleksi dan Evaluasi}

Hasil supervisi monitoring dianalisis untuk dijadikan bahan pikiran dalam merefleksi kegiatan selama kegiatan dilakukan. Pada tahap ini dilihat sampai dimana kegiatan penguatan dan pengembangan ekonomi pesantren ini dapat dilaksanakan melalui pendampingan. Persoalan-persoalan yang muncul dicarikan pemecahannya dan dilakukan perbaikan 
sehingga ditemukan model pengembangan ekonomi pondok pesantren yang efektif dan efisien.

Berdasarkan hasil supervisi monitoring maka dapat dianalisis bahwa keberhasilaan usaha penggemukan sapi oleh pengelola pesantren, ternyata sangat dipengaruhi oleh: (1) Komitmen dan kepemimpinan kiyai. 2). Potensi dan pengalaman kegiatan penggemukan sapi sebelumnya; 3). Keseriusan dan motivasi pengelola dalam menerapkan hasil orientasi, dan 4). Efisisensi dan efektifitas penggunaan dana bantuan.

Kegiatan evaluasi dilakukan di luar kegiatan supervisi monitoring. Kegiatan evaluasi ini merupakan kegiatan yang dilakukan untuk mengetahui sejauhmana tujuan, target, dan sasaran program penguatan dan pengembangan ekonomi dapat dicapai. Kegiatan evaluasi dapat dilakukan dengan melihat capaian hasil baik melalui pengamatan secara langsung maupun laporan kegiatan. Hasil evaluasi juga dapat digunakan sebagai informasi yang digunakan untuk memberikan masukan perbaikan pada kegiatan selanjutnya. Kegiatan evaluasi juga bisa menyangkut persoalan proses dan produk, sebelum dan sesudah program dilaksanaan, dan perbandingan antara 5 pesantren program.

Hasil evaluasi menunjukkan 5 pesantren telah melakukan usaha penggemukan sapi dengan baik, namun dari tingkat keberhasilan maka Roudlotul Mutaalimin menduduki ranking pertama, diikuti PP Mazroatul Fatah, PP Al-Jihad, PP Al-Kaustar dan PP Al-Islam. Keberhasilan ini semua karena dukungan kuat Kiyai dan seluruh pengurus usaha penggemukan sapi. Rata-rata dana pengembangan hanya digunakan untuk pembelian sapi, dan obatobatan, sedangkan untuk biaya kandang dan pakan dikelola oleh pengurus.

Para pengelola penggemukan sapi pesantren penting untuk diberi kesempatan mengembangkan usahanya dengan bantuan pendampingan dinas peternakan setempat secara berkesinambungan. Karena pengembangan usaha penggemukan sapi pada dasar- nya terkait dukungan semua pihak di samping dukungan potensi ekonomi yang dimiliki pesantren.

\section{Hasil Pencapaian Program}

Penelitian terapan tentang program pengembangan potensi ekonomi pesantren di Lamongan Jawa Timur tahun 2010 merupakan sebuah "exercise" apakah lembaga pesantren yang selama ini lebih dikenal sebagai pusat kajian ilmu agama, mampu memerankan diri sebagai pusat kegiatan ekonomi. Kelima pesantren dengan satu jenis usaha ekonomi yang sama, diperlakukan treatmen sama; mulai dari orientasi/pembekalan, pemberian dana pengembangan, kesempatan penerapan dan replikasi program, supervisi monitoring, serta proses pendampingan.

Dalam kenyataan terjadi keseragaman tetapi juga keragaman dalam capaian programnya. Hal tersebut dikarenakan terdapat sejumlah faktor yang menjadi penentu baik yang mendukung maupun yang menghambatnya.

Pertama, Pondok Pesantren Al-Jihad yang berlokasi di daerah Pantura (Pantai Utara) tepatnya di desa Banjarwati Kec. Paciran kabupaten Lamongan. Pesantren ini berdiri pada tanggal 09 September 1999, memiliki lembaga pendidikan Kejar Paket B dan C, Madrasah Diniyah tingkat Ula, Wustho dan Madrasatul Qur'an (MQ), MTs dan MA Al-Azhar, dengan diketuai oleh pengasuhnya sendiri yakni $\mathrm{K}$. Mustaji, S.Ag, M.Ag..

Mengingat letak pesantren ini dipedesaan pantura yang masih banyak pertambakan, perkebunan dan persawahan maka banyak potensi agribisnis yang bisa dikembangkan dipesantren ini. Baik pertambakan, peternakan maupun pertanian. Dalam bidang usaha ekonomi pesantren, pesantren Al-Jihad telah memiliki asset usaha yang dikembangkan antara lain: koperasi pondok pesantren, kantin Pondok pesantren, LM 3 untuk menunjang pengelolaan dan pemberdayaan pondok pesantren, penggemukan sapi, snack (produksi krupuk dan nasi bungkus), depot isi ulang, dan tambak 
ikan dan udang. Pesantren ini telah memiliki SDM yang trampil dalam melakukan usaha pengembangan ekonomi pesantren.

Terkait dengan program penggemukan sapi, pesantren Al-Jihad melakukan pemanfaatan dana pengembangan yang lebih diarahkan pada pembelian sapi, sedangkan untuk kandang telah dimiliki sebelumnya, biaya pengobatan dan perawatan lebih pada swadaya pesantren itu sendiri. Faktor yang mendukung adalah factor geografis, dan iklim cocok bagi penggemukan sapi. Factor penghambatnya lebih pada dana operasional yang masih kurang. Program ini cukup berhasil dalam mendongkrak nilai ekonomi pesantren.

Kedua, Pondok Pesantren Mazro'atul Fattah Al-Maliky berlokasi di Siman Sekaran Lamongan. Keberadaan Pondok Pesantren Mazro'atul Fattah Al-Maliky sebagai sarana pengembangan Dinul Islam memiliki arti yang strategis dalam mewujudkan masyarakat madani yang dibagun diatas institusi kelembagaan yang kuat, mandiri dan mengakar dimasyarakat.

Pesantren Mazro'atul Fattah Al-Maliky melaksanakan suatu program Bantuan Dana Penggemukan Sapi untuk memberikan bekal ketrampilan kepada santri dan untuk menciptakan lapangan pekerjaan bagi masyarakat yang ada disekitar pondok. Dengan adanya dana bantuan dan Litbang Kementerian Agama RI maka terjadi kerjasama yang baik antara pemerintah dan pesantren dalam mewujudkan perekonomian pesantren; munculnya wirausahawan serta terwujudnya silaturrohhim pesantren dengan masyarakat sekitar. Dengan posisi seperti ini, pesantren Mazroatul fatah menjadi sebuah lembaga yang diminanti masyarakat karena di dalamnya tidak hanya kegiatan yang bersifat rohani saja tetapi dibina pula masalah ekonominya.

Ketiga, Pondok Pesantren Al-Islam Tenggulun didirikan pada tanggal 27 September 1992, dari tahun ketahun perkembangan Pondok Pesantren Al-Islam mengalami jumlah santri yang selalu meningkat. Peranan Pondok Pesantren Al-Islam tidak hanya menekankan dibidang pelayanan saja tapi sekaligus bagaimana mengentas anak didik menjadi manusia beriman, bertaqwa dan berahlakul karimah serta menjadi Ulama 'Amilin Sholihin yang dapat diterima ditengah-tengah masyarakat luas.

Kabupaten Lamongan pada umumnya adalah memiliki Potensi Agraris, maka Pesantren Tenggulun Solokuro Lamongan, mengembangkan potensi tersebut dengan melakukan peternakan sapi, penanaman jagung dan pada umumnya melakukan usaha-usaha dimaksud sehingga perlu adanya kerjasama antar Pondok Pesantren dan Masyarakat. Adapun hasil produksi dapat di pasarkan ditingkat lokal karena masyarakat senantiasa butuh untuk qurban idhul adha, kebutuhan perkawinan dan kebutuhan rumah tangga.

Maksud dan tujuan diadakannya usaha penggemukan sapi, agar supaya melibatkan masyarakat dan santri Ponpes secara langsung sehingga dapat menunjang kehidupan ekonomi masyarakat dan sekaligus dapat menghidupkan dan mengembangkan pesantren. Sasaran yang ingin di capai adalah masyarakat merasakan secara langsung tentang manfaat keberadaan Ponpes melalui LM3 yang dapat menunjang kehidupan ekonomi mereka, PP Al-Islam / LM3 hidup menyatu dengan masyarakat dan pentingnya hidup saling memberikan sehingga penguatan ekonomi, masyarakat dan Ponpes Al-Islam dapat di rasakan sehingga ketahanan dan keamanan dapat di rasakan bersama.

Dalam pengembangan budidaya sapi potong di daerah kabupaten Lamongan Jawa Timur dimana ketersediaan bahan baku seperti rumput,jagung, dedak sangat melimpah. Untuk sementara bahan baku tidak di manfaatkan, karena masyarakat di Kabupaten Lamongan yang memelihara sapi. Program penggemukan sapi potong adalah sangat menguntungkan serta peluang pasar di Kabupaten Lamongan sangat terbuka, karena sementara ini kebutuhan akan daging sapi di Kabupaten Lamongan masih di datangkan dari luar daerah, itupun masih kurang untuk memenuhi kebutuhan masyarakat 
belum lagi pada hari-hari keagamaan permintaan akan daging sapi sangat meningkat.

.Keempat, Ponpes Raudlatul Mutaallimin merupakan lembaga yang berada di bawah naungan Yayasan Pondok Pesantren Raudlatul Mutaallimin Tegalrejo Datinawong Babat Lamongan. Akte Notaris: Masruchin, SH. M.Hum. No: 4/2010/SK Menkumham No: AHU-651.AH.01.04.Tahun 2010. Alamat Pondok Pesantren Raudlatul Mutaallimin adalah: Jl. Raya Babat - Surabaya. Tegalrejo Datinawong Babat Lamongan. Pondok Pesantren Raudlatul Mutaallimin, berlokasi di sebuah Desa, tetapi hanya berjarak $+5 \mathrm{~km}$ di sebelah timur kota Babat. Berjarak 10 meter sebelah selatan Rel Kereta Api dan 20 m sebelah selatan Jalan Raya Surabaya - Jakarta, sehingga suasananya tidak terlalu sepi dan tidak terlalu hiruk pikuk keramaian kota. Namun dari segi ekonomi masyarakat, sangat memprihatinkan, karena + $85 \%$ dari jumlah penduduk kerjanya adalah sebagai pedagang asongan, di terminal-terminal, pasar-pasar, dsb. Hal itu di sebabkan karena pertanian di desa ini dan sekitarnya masih tadah hujan, sekali panen dalam satu tahun dan sering merugi.

PP Raudlatul Mutaallimin memiliki usaha penggemukan sapi, Usaha ini dilakukan agar supaya masyarakat dan pihak Ponpes terjalin hubungan kerjasama yang positif terutama dalam upaya bersama meningkatkan kesejahteraan, baik dalam menunjang kehidupan ekonomi masyarakat dan sekaligus dapat menghidupkan pesantren.

Dengan adanya pengembangan usaha penggemukan sapi, masyarakat di sekitar pesantren sangat mendukung terutama dalam penyediaan lapangan kerja. Masyarakat sekitar terutama dari kalangan wali santri merasa dilibatkan dalam usaha penggemukan sapi potong. Pondok pesantren juga sangat terbuka bagi masyarakat sebagai tempat belajar penggemukan sapi. Program penggemukan sapi di pesantren ini tampak semangat, bahkan pesantren dapat mengembangkan pondoknya dengan usaha ekonominya, disamping adanya dukungan masyarakat.
Kelima, Ponpes Al-Kautsar merupakan lembaga yang berada di bawah naungan Yayasan Pondok Pesantren Nurul Jami Al-Kautsar. Pondok Pesantren Nurul Jami Al-Kautsar, berlokasi di sebuah Desa Manyar Kecamatan Sekaran Kabupaten Lamongan. Pondok pesantren ini merupakan sebuah pondok yang sangat konsen terhadap usaha pengembangan ekonomi, termasuk usaha penggemukan sapi. Usaha penggemukan sapi merupakan salah satu asset yang dapat menjalankan roda perjalanan pondok pesantren. Dengan adanya pengembangan usaha penggemukan sapi, masyarakat di sekitar pesantren, terutama wali santri yang kurang mampu terlibat dalam usaha ini, sehingga dapat meringankan beban biaya sekolahnya. Di samping itu dengan adanya pengembangan usaha penggemukan Sapi masyarakat di sekitar dapat terbantu terutama dalam penyediaan lapangan kerja dan juga kami pihak pesantren terbuka bagi masyarakat sebagai tempat belajar berternak sapi potong.

Kegiatan pelaksanaaan dana bantuan usaha penggemukan sapi dari pemerintah, dalam hal ini Puslitbang Penda mengalami perkembangan yang baik. Muncul adanya temuan temuan kemajuan usaha tersebut, disamping adanya kendala yang dihadapi namun secara umum berjalan dengan lancar. Dengan adanya usaha ini terciptalah pemberdayaan ekonomi pesantren, pemberdayaan masyarakat sekitar terutama wali santri dan terwujudnya silaturrohim pesantren dengan wali santri.

\section{PENUTUP}

\section{Kesimpulan}

Secara umum pengembangan ekonomi pesantren melalui program penggemukan sapi, di lima pondok pesantren Kabupaten Lamongan berjalan sesuai hasil orientasi. Semuanya dapat dibuktikan misalnya melalui pemanfaatan dana pengembangan yang lebih diarahkan pada pembelian sapi, sedangkan untuk kandang dll lebih pada swadaya pesantren itu sendiri. 
Pengembangan ekonomi pesantren melalui program penggemukan sapi, di lima pondok pesantren Kabupaten Lamongan adalah cukup strategis, terutama dilihat dari factor geografis dan iklim yang cocok, meski ada juga faktor penghambatnya yaitu lebih pada dana operasional yang masih kurang. Usaha ini juga terbukti terjalin hubungan kerjasama yang positif antara masyarakat dan pihak Ponpes terutama dalam upaya bersama meningkatkan kesejahteraan, baik dalam menunjang kehidupan ekonomi masyarakat dan sekaligus dapat menghidupkan pesantren. Dengan posisi seperti ini ke depan pesantren dapat menjadi sebuah lembaga yang banyak diminanti masyarakat karena di dalamnya tidak hanya kegiatan yang bersifat rohani saja tetapi dikembangkan pula masalah ekonominya.

Implementasi pengembangan ekonomi pesantren melalui program penggemukan sapi di lima pondok pesantren Kabupaten Lamongan merupakan hasil refleksi dari apa yang dilihat dan diperoleh dari Pondok Pesantren Sunan Drajat Lamongan. Di samping itu adanya forum komunikasi antara 5 pengelola penngemukan sapi dari 5 pondok pesantren di Lamongan yang komunikatif dalam mengatasi persoalan bersama program penggemukan sapi. Dalam mengatasi persoalan yang berat, forum komunikasi mengkomunikasikannya dengan dinas peternakan Kabupaten Lamongan dan expert dari UNER Surabaya yang sejak semula mengawal program penggemukan sapi. Dengan keberhasilan program penggemukan sapi pada 5 pondok pesantren ini menjadi sebuah model pengembangan ekonomi pesantren tersendiri.

\section{Rekomendasi}

Berdasarkan pemaparan kesimpulan tersebut di atas maka dapat direkomendasikan beberapa hal sebagai berikut:

Perlu adanya pengembangan ekonomi pesantren lebih lanjut melalui program lanjutan tentang pengembangan ekonomi pondok pesantren, sehingga pesantren mampu menyempurnakan program ini. Namun, hendak- nya perlu dilakukan secara bertahap, terfokus , terprogram dan dapat terukur tingkat keberhasilannya.

Melalui program pengembangan ekonomi pesantren ke depan dapat memicu pesantren tidak hanya mengelola kegiatan yang bersifat rohani saja tetapi dikembangkan pula masalah ekonominya. Namun demikian dalam kelanjutan pengembangaan ekonomi pesantren perlu terus dibangun kemitraan dengan dinas peternakan setempat.

\section{SUMBER BACAAN}

Afrizal Woyla Saputra Zaini, Pembangunan Pemberdayaan Masyarakat, 20 Februari 2011, http://afrizalwszaini.wordpress. com/2011/02/20.

Al-Islam Pondok Pesantren Islam, (2010) Laporan Pelaksanaan Program Pengembangan Ekonomi Pesantren

Al-Jihad Pondok Pesantren, (2010) Laporan Pelaksanaan Usaha Ekonomi Pesantren

Al-Kautstar Pondok Pesantren, (2010) Laporan Pelaksanaan Program Pengembangan Ekonomi Pesantren

Departemen Pekerjaan Umum, Direktorat Jendral Cipta Karya, Modul Dasar Pemberdayaan Masyarakat, PNPM Mandiri, http:// id.search.yahoo.com/search; _ylt=A0oG kmFnMHpRWXcANRPLQwx.?p=pemberdayaan +masyarakat\&ei=UTF-8\&fr=yfp-t713-s\&xargs $=0 \&$ pstart $=1 \& b=11$

Gay, L.R. Educational Research, Competence for Analysis and Application (New Jersey: Merril an Inprint of Prentice hall, 1996).

http://www.pengertiandefinisi.com/2012/02/ pengertian-supervisi.html, Monday, February 27,2012

http://www.lebahndut.net/2012/11/apa-itusupervisi-definisi-pengertian-supervisi. html, di ambil dari buku "Effective Supervision" karya Wayne K. Hoy dan Patrick B. Forsyth. 
Hhttp://id.wikipedia.org/wiki/Pemberdayaan_masyarakat, Ensiklopedia bebas Wikipedia bahasa Indonesia, devinisi ini diambil dari James A. Christenson \& Jerry W. Robinson, Jr Ames (edited): Iowa State University Press, 1989, Community development in perspective.

Hhttp://tesisdisertasi.blogspot.com/2010/03/ pengertian-pemberdayaan-masyarakat. html.

Http:// Green Blue-Phinisi.Blogspot. com/2009/03/Upaya Pemberdayaan Masyarakat, di-bidang.html.

Indra K.Nasution, (2009), menjembatani _penelitian_dan_kebijakan, http://id.wikipedia .org/wiki/Monitoring

Indra K.Nasution, (2009), menjembatani _penelitian_dan_kebijakan, Http://www. smeru.or.id/reporttraining
Lynton, Rolf P. dan Udai Pareek, Training for Development, (West Haretford, Conecticut, 1978).

Mazroatul Fatah Pondok Pesantren, (2010) Laporan Pelaksanaan Program Ekonomi Pondok Pesantren

Mujamil Qomar, (2006) Pesantren Dari Transformasi Metodologi menuju Demokratisasi Institusi (Jakarta: Erlangga)

Roudlotul Mutaalimin Pondok Pesantren, (2010) Laporan Pelaksanaan Usaha Ekonomi Pesantren

Sarwani, Penguatan Kelembagaan Ekonomi Pesantren, (makalah disampaikan pada orientasi program pengembangan potensi ekonomi pesantren, Juni 2009) 